\title{
Philosophy, Feminist Literary Criticism and “The Difference”
}

\author{
Luisa Posada Kubissa \\ Complutense University, Madrid, Spain
}

\begin{abstract}
This paper discusses the present-day philosophical rupture away from identitarian thinking, and how the former has influenced the world of the feminist literary criticism of today. Herein, we embark on a journey from its awakenings back in the 1960s. We begin our quest with Kate Millett, we will continue our discussion with Irigaray, Cixous, or Kristeva and their analysis of the difference created by gender. And, we will reflect on the influence it has made to the American movement. We use the aforementioned as the lead towards the theory of deconstruction in authors such as Felman or Spivak, and how we reach the concept of performativity of gender in line with Butler and the queer theory.
\end{abstract}

Keywords: feminist literary criticism, sexual difference, deconstruction

\section{Introduction: From Criticism to the Feminine Voice}

From its origins, feminist theory has been political, not in vain does the Spanish philosopher Celia Amorós discuss "la entraña politica" (the political core), of feminist thinking. Hence it should be understood as part of a political objective: criticize structures of marginalisation and discrimination of women in literary fields.

In the radical contemporary feminism from the end of the 1960s, we witnessed literary criticism with a political aim. And, contemporary feminism is in turn, heir to the so-called first-wave feminism; in other words, the inheritor of the suffragette tradition and the Age of Reason. Radical feminism, as a case of contemporary neo-feminism, is all intertwined with the demands for political rights for women and the female liberation movement's vindication for sexual freedom. This feminism had strong links with the various factions that formed The New Left in North America. These factions were all united in opposing the Vietnam War. By the mid-70s feminism declared itself a radical self-sufficient movement. Feminism did not want to be encapsulated within any of the other organisations or the other factions considered left-wing parties.

It is within this context, where we first witness feminist literary analysis. It was, in particular, The Second Sex by Simone de Beauvoir that provided its theoretical basis. This first foray into feminist literary criticism was brought to us by familiar figures such as Kate Millett, Elaine Showalter, and Gilbert and Gubar.

On the subject of feminist literary criticism, we are describing a heterogeneous range of research mind-sets. All are, however, united in their criticism of androcentrism and fed by contemporary philosophical developments. Taking into account Toril Moi's considerations (Moi, 1985), we would have, on one side the representatives of the literary criticism (as the above mentioned Millett, Showalter, and Gilbert and Gubar), and on the other side the authors more related to theory (such as Beauvoir, Irigaray, Cixous, and Kristeva).

At this point, we need to look at the conflict of two separate views, both present in contemporary feminism: difference and equality. And it is here, within these paradigms that a rather more globalised understanding of

Luisa Posada Kubissa, Ph.D., Faculty of Philosophy, Universidad Complutense de Madrid. 
feminism is held, a feminism that is able to permeate all those areas where it is applied. The second-wave of feminism broadened the issue towards the demand for gender equality. Difference feminism burst through into feminism at the end of the 1970s. It was born out of the need to explain the generic duality, male and female. Whether difference feminism can be explained as a part of biological essentialism or as part of a socio-cultural construction, it was the theorisation around the subject which placed it at the core of the debate. For literary analysis, this would mean a reaffirmation of culture and literature, specific to and belonging to women.

Immediately before this debate, we find Kate Millett. Kate Millett's work centres on the revisiting of the literary writings of some of the authors best loved by the North American left-wing movement. Millett does this to demonstrate their prevailing patriarchalism. Millett also points to the imagery of femininity emerging from these writings which would open a door to gynocentric criticism; this line of thinking vindicates experiences which are specific to women in literature. After Millett's reflections, the existence of a female literature, differentiated from gender aesthetic codes is started to be considered.

Sexual Politics (Millett, 1970), a book by Kate Millett based on her Ph.D. dissertation, can be considered one of the first, or perhaps the first dissertation, known to be gender based. In it, Millett turns her attention back to the prevailing thought of the leftist undergraduate movement at that time. That is, she revisits Marxism and psychoanalysis and puts them at the service of critical feminist research.

Millett's essay is known to give new meanings to certain concepts taken from other scientific areas i.e., the term "patriarchy". This term has its origins in the works of anthropologists such as Morgan or Bachoffen, but is made popular by Engels in his book The Origin of the Family, Private Property and the State, published in 1884. In his book, Engels mentions a supposed matriarchy as the origin of society: according to this hypothesis women would have had the power in prehistorical times. This power would have been taken away from them during a coup, giving birth to patriarchy. Contemporary anthropology discards this theory which mixes up matrilineal decent, a system in which a person's descent is traced through their mother and her maternal ancestors, and matrilocal, a term referring to the societal system in which a married couple resides with or near the wife's parents, with matriarchal systems, where women would have held the power. Kate Millet takes interest in the notion of patriarchy and provides a new meaning to it. As Millett used the term, it was meant to characterize a society dominated by one gender whose primary purpose is to construct and maintain a certain power relationship over the other. This type of relationship between man and woman seems to appear at all levels, even on a more personal or private level.

Millett's specific objective is no other than the complete abolition of patriarchy. To this end, Millett's notion is understood as the dominance of a group of society based on gender rather than class. In her analysis, Millett includes the historic journey of the suffragette movement and will use this as a starting point in her quest to map out a political overview up to the 1960s. A panorama crisscrossed by counter-revolutionary ideologies such as Nazism or Stalinism.

In her analysis, Millett describes the colonisation suffered by women by a male culture. She examines patriarchy and describes it as a subjugation of women and young males by older males. Millett recognizes that some early primitive societies prior to the modern age would have allowed women to participate more extensively in the running of politics than present-day democratic systems do. Millet refers to the reproduction of patriarchy based on ideological (caused by socialization of gender), and biological aspects (built upon biological differences as presented in Freudian theory, always according to Millett). 
Based upon these findings, Millett tackles in the third part of her book Sexual Politics. Millett directs her criticism to some of the most revered writers in the literary canon. Millett notes how D. H. Lawrence, Norman Mailer, and Henry James all make for a misogynistic and patriarchal discourse in their literary works. In her criticism, Millett omits discussion of some of the more formal or literary aspects of their production. Rather, she highlights their ill-treatment of women and their general outlook on all things feminine in all their creations.

Millett then takes a feminist stance and accuses her left-wing allies of patriarchal behaviour. For instance, on Henry Miller she says that although Miller is a renegade he is someone who hates mercantilism with all his soul. Yet, mercantilism is so engrained in him that he finds it impossible to renounce. Miller merely transfers it into sex and he turns women into a commodity (Millett, 1995, p. 503).

However, for Millett, analysis would not prove to be sufficient in to build up a strong feminist literary criticism. At least, Elaine Showalter understands it this way. In Towards a Feminist Poetics (Showalter, 1986) Showalter puts forward the idea of criticism from a gynocentric perspective. Showalter argues for a theorisation centred on women and oriented to them. The female experience becomes a category, which must be considered central to her brand of literary criticism. In Literature of Their Own, Showalter sets the stage for women writers, once household names but then largely forgotten, of the English speaking world (Showalter, 1977). This study includes assessments of writers from the Brontë sisters all the way to Doris Lessing.

In keeping with this gynocentric line, in 1979, Gilbert and Guber examine Victorian literature from a feminist perspective, putting forward the literary paradigm of "confinement, madness and escape”, as a literary feminist paradigm:

We conclude that the startling consistency in literature written by women could be explained in their motivation to liberate themselves from a social and literary confinement. And these objectives are achieved by revisiting concepts such as art, society and self. (Gilbert \& Gubar, 1998, p. 12)

I will not be making any further incursions in this line of literary criticism but I would like to point out that this groundwork discovers a female literary tradition in direct contrast to the identity developed by male authors. According to Gilbert and Gubar, the feminine identity comes about because of a feeling of guilt caused by a futile effort to accommodate the prevailing standards rather than their eagerness to rebel.

The outlook of sexual difference at the genesis of feminist literary criticism moves from an appraisal of patriarchalism and androcentrism within some of the most revered male authors of the literary canon, to the profiling of a specific difference within a literary work created by women. But difference in feminism, which generates a theory of sexual difference, will appear above all in France and will make real inroads by the end of the 1970s.

\section{The French Difference and Its Reception in the United States}

The difference in French feminism comes to light with the deconstruction of French philosophers like Jacques Derrida or Jean Deleuze. It also recovers some conceptual tools from post-Freudian psychoanalysis of Jean Lacan. Lacanian thinking understands sexual difference as just another form of identity (these could include gender, cast, ethnicity, etc.), produced discursively through language. Hence, identity is not inherited but it is rather an effect or a by-product and therefore female identity cannot be treated as something already established or fixed. 
In titles such as Of Grammatology (Derrida, 1967) or Dissemination (Derrida, 1972), Derrida questions western beliefs in excessive logocentrism, reasoned as the epistemological centre for truth and law. This model formats the history of thinking into a dichotomised structure with two binary sides set up hierarchically. Deconstruction according to Derrida, should move towards the breaking up of logocentrism and the acknowledgement of "la différence": "la différance" understood with its double sense, that which is different and that which is delayed. This is made evident by Ferdinad de Saussure. Saussure contends that words have meaning only because of contrast-effects with other words. And it is this property which gives meaning to characters. Understanding logos and phallus in the Lacanian sense as a metaphor synonymous with power, Derrida censures phallogocentrism, which arranges practice and the constitution of subjectivity in a masculine manner. This idea is taken up by the French philosopher Luce Irigaray, who formulates the question, how can it be possible, for a woman to speak up within a system that solely represents the male gender? An alternative would be found within the deconstruction of this phallogocentrism system. Irigaray leads us in this direction with the deconstruction of texts by Sigmund Freud and Jacques Lacan in her work Speculum of Other Women (Irigaray, 1974). In accepting psychoanalysis as fundamental for feminist theory with regards to explaining sexual socialization, Irigaray understands psychoanalysis should also be criticised, as long as it continues to function within an androcentric and patriarchal system.

Luce Irigaray feels attracted to the Lacanian theory of the mirror stage in order to apply it to feminine subjectivity. According to Lacan, during the pre-Oedipal phase of development, the child experiences a symbiotic stage. During this period, the boy or the girl is unaware of any difference there might exist between the $I$ and the you. The mirror stage triggers the process of self-awareness from the age of about 6 months, until the 18 months.

Next is the vital moment of subjectivity. It will be at this phase, when we see the advent of father's law, the arrival of speech, which will coincide with the boy/girl self-identifying and the break up the former identification with the mother. But this moment leads to two very different paths: The boy will identify with "the same", meaning he enters a symbolic order of male. The girl on the other hand, is ostracized from the pre-Oedipal bond and is left to the mercy of the pre-established male order, which will exclude her, for she is part of "the other", "the different". And femininity is left on the margins of language and eccentric. And it is exactly from there from where the female difference can be rescued: this difference has been lost but not destroyed, according to Irigaray.

The male-female difference already established and originating from a male-oriented blue print, calls upon a new practice of writing, a writing which is suppressed by the already established symbolic male order. The above mentioned path is chosen by Hélène Cixous, who feels strongly influenced by Derrida's thinking. Whereas Irigaray's dialogue centres on "parler-femme", Cixous directs her interest to the feminine writing side, as she considers it key to women's quest to rebel against the censorship posed by male rationality. In her programmatical manifesto La Rire de la Méduse (Cixous, 1995), published in 1975, Cioux's intention is to open up a new form of linguistic expression. This new form will be in accordance with a specific feminine writing style, which turns to rhythm and tone and is closely linked to the voice and the human body.

Feminine writing as suggested by Cixous, is not created in response to any natural gender difference. Instead, Cixous speaks about male versus female economics, not attached to biologic sex. Hence, men able to apply women economics will at the same time be able to practice female writing by allowing the female to flow, 
as a way of overcoming phallogocentrism through a more feminine body-language in writing. To this end, she writes

We like inquisitiveness and curiosity, at times there is waste in what we say. We need those scraps. Writing, destroying the exchange value that keeps the word on its tracks, it's like giving the surplus and the pointless a wild side. This is why it is good to write, allowing the words to flow, as one would allow a caress. To take the time one needs to complete a sentence, a thought, to make one be loved, to reverberate. (Cixous, 1995, p. 55)

Conveying female writing in La Jeune née, 1975, written in conjunction with Catherine Clément, Cixous alludes to an economy that unites body, femininity, and text. The aim, she explains, is to write texts that do not work as male bodies.

In addition to essays on deconstruction of text, such as Entre l'ecriture, 1986, Cixous has devoted her time to writing novels, poetry, and theatre, putting into practice her own theorisation on feminine writing. On her own creative foray she has uncovered the Brazilian writer Clarice Lispector, whom she describes as her "literary paradigm". According to Cixous, the constant use of metaphor, poetic language, and use of semantics and syntax in order to distance herself from the pre-established norms of male writing, makes Lispector the best there is in écriture féminine.

Returning for a moment to Irigaray, our scholar suggests in Speculum a deconstruction of the tradition of western thinking and its vision of all things feminine. In Plato, Aristotle, Descartes, Kant, and Hegel, she finds places in need of deconstruction. Irigaray achieves this via mimesis. By mimesis, one should understand Irigaray in not revisiting, using, or citing renowned texts of the above scholars. Rather, she is paraphrasing them, discussing them, putting their mechanisms and structures into play. This strategy of repetition points to a deconstruction of text and above all a deconstruction of the imperious effect of such wording. The objective for Irigaray is not deconstruction per se. Instead, it is to show or reveal sexual difference, to substantiate that the human being and therefore the subject is two. This is what she said in 1992:

Nature is two, the natural is at least two: male and female. Unless you believe that men and women are identical in every way-including physically_you have to accept that the universality of «the human being» does not exist. (...) In the same way, for these two parts that are woman and man. Only through discrimination they are reduced to one. Reason shows in this reduction, its impotence or perhaps its immaturity. (...) Humanity, after all, may not have reached the age of reason just yet. (Irigaray, 1994, pp. 57-58)

According to Freud, the female identity is determined by a lack of penis and the resulting prejudice; according to Irigaray, the area of identity or feminine difference will be found in the morphology of the labia. This metaphor plays an important role in the description of "parler-femme". This is a speech that makes use of this very genital morphology:

Though this may all sound contradictory and a little crazy for the logic of reasoning, and hushed perhaps for those who listened with preconceived ideas and a predisposed code of values. In her assertions-when she there speaks-woman is constantly going over her herself-so to speak-. She merely separates from herself a certain verbalisation, an emotional utterance, a «known» secret, unfinished words-whenever she revisits these words, she creates a new point of view, of pleasure, of pain. We must listen in contrast, we must play attention to «the next/other meaning», a meaning in constant evolution. She is constantly caressing her words, purging them for they mustn't grow roots, become immobilised. When «she» says something, it is no more the same. Furthermore; her assertions are ever-changing, never the same. Her most distinctive trait is her contiguity. They touch (each other). And when they wander too far from this proximity, she stops, and she starts from «cero» once again: her bodysexual organ. (Irigaray, 1997, pp. 326-327) 
The irreducible sense of female difference is what sets Irigaray apart from Derrida's post-structuralism because in parler-femme, Irigaray plays with a reversal of categories, rather than their outright deconstruction. And it is from this category-reversal, that female logic is opposed to male logic, taking its roots in the sexual difference.

Taking Lacan and Derrida theorization as a starting point, Julia Kristeva, born in Bulgaria, 1941, is associated with the French feminism of "difference". She takes particular interest in the relation of difference and discursive subjectivation. Of all scholars of the time, Julia Kristeva is the closest to postmodernism; partly because of her close ties with semiotics research and partly due to her continuous references to Lacan, a principal reference in this field.

Kristeva distinguishes the semiotic from the symbolic; the former, is directly linked with the Lacanian pre-Oedipal phase. Here, the advent of the law and the language of the father have not appeared yet. The semiotic side conveys poetic speech in contrast with symbolic sense and structure. Kristeva theorizes that the pre-Oedipal phase, prior to any rupture from primal maternal links, as in the aforementioned Lacanian mirror stage analogy. In The Revolution in Poetic Language, Kristeva (1974) develops not just a theory of difference as Irigaray or Cixous does, but a theory of dissent. Kristeva refers to a semiotic type. Here woman is often referred to, as the maternal body or pre-linguistic body. According to Kristeva, the poetic text would correspond to the pre-Oedipal semiotic moment and the female identity is understood not in the essential way of Irigaray but in a more strategic sense. This strategic identity is best and more accurately expressed by the Spanish philosopher Rosa Maria Rodriguez Magda: It would all be about, according to Rodriguez Magda,

woman needs to adopt a specific material entity as well as a simulated and multiple one. Combine pluralism and fragmentation: be several when pigeon-holed into a pre-established and alien identity, but at the same time, a well-defined entity when the purpose is to nullify us. (Rodriguez Magda, 1999, p. 138)

Irigaray, Cixous, and Kristeva all theorise about feminine difference's links with language. Notwithstanding, all through fairly different theoretical paths, but with a common element: their need to break away from the route traced by the dominant symbolic thinking and in another way, to go beyond deconstruction and recover a more positive female identity.

The Anglo-American scene will be aware of the French feminism of difference, taking special interest in their analysis of sexual difference cloned through the production and reproduction of language. This leads to a turning point towards a linguistic theory, for a group of feminist thinkers. Specifically, a group of scholars stemming from Yale University: Shoshana Felman, Barbara Johnson, or Gayatry Chakravorty Spivak among others. The feminist deconstruction of Yale University arises from a radical constructivism. It rejects outright the prospect of biological determiners and interprets gender identity as a purely socio-cultural determination.

Special consideration to Spivak who represents a new found direction on subaltern speak, a founding text for post colonialism or subaltern studies. Spivak from her interdisciplinary academic world pledges a postcolonial literary theory, using race, class, and gender. Spivak practices a very practical reading, leading, and decoding the language of subjugation and repression. "Three women's texts and critique of imperialism" (Spivak, 1985) points to Derrida's text, and while accepting his influence, she considers it a way of cooperating with the rooted gender difference from the basic preconception of what women are. Spivak censures the Derridean notion of "différance". According to Spivak, the sexual identity, is related to "la différence", rather than a sexual difference; and so, it is "la différence" instead of "the difference" that differentiates genders 
(Spivak, 1993, p. 132). Based on the above, we find a double entendre "différence" and woman. We are giving an identity to a term we are trying to deconstruct. Spivak reaches a conclusion: the term "woman" must be disregarded. And so, this is the authentic path towards a deconstructive feminism. Such feminism must entice differences to be considered from "within" the differences, rather than "among” them. Only then we would be able to fashion "the difference" within its true radical framework.

Keeping close tracks on Spivak's work and writing multiple texts with "the difference" as main focus (Johnson, 1998; 1997; 1980), Barbara Johnson states that deconstructive feminism cannot be understood as destructive feminism; rather the opposite. One needs to reinforce the original meaning of the term "deconstruction", as critical analysis. Johnson champions analytical reading of texts that will dissect any patriarchal or domineering structure and turns our attention towards the marginalised or precluded in the remaining text.

Soshana Felman, from the same Yale group, addresses the relationship between psychoanalysis and literary theorisation, revisiting the theory of John L. Austin and his contribution to the philosophy of language. Austin makes a clear distinction between acts of speech, dividing them into constative and performative acts. Performatives, describe behaviour in the speaker, as opposed to constatives, which describe either falseness or truth. Felman believes Austinian theory to be conducive to an association of deconstruction and psychoanalysis: Performative speech does not relate to the truth in the way constative does. It is not representative, and therefore, it is fundamentally self-referential (Felman, 1983, p. 33). This self-referring element allows access to psychoanalytic unconscious. In literature, it takes us on a trail of discovery. We are able to observe what stays outside the truth and at the same time obtain knowledge in the constative sense. Felman, recommends allowing the text to free the meaning, instead of interpreting meaning based on readings. Thus, it is not just reading as a woman, interpreting how the text sets the sexual difference, rather, one must recognize it, highlight how the difference underlies the text throughout. Felman ponders What does a woman want? (Felman, 1993, p. 10): the answer to this question is in the understanding of the term femininity and difference as an open concept. In it, gender identity is neither pre-established, nor fixed. It cannot be identified unequivocally.

\section{Current Developments: Notes on Queer Theory}

Cultivating certain differences such as femininity or masculinity has the effect of changing the way we look at feminist literary criticism and its theorisation. What are the effects of moving from a socio-cultural angle to a deconstruction perspective? We need to navigate from a conceptualisation of the female identity to an acknowledgment of the deconstruction of identities. Once we reach this point, we can opt out of the need to adhere to a feminine subjectivity by virtue of questioning gender identity and thus we see the birth of the queer theory by the end of 1980s/start of the 1990s. And so, research on women and gender theory spawns queer studies.

In this context, and within a literary and cultural criticism, the subject is understood as a product of the relationship of power, speech, and some subjectifying and explicative practices. In the wake of Foucaultian thinking, the subject is estranged from an original position to be thought as the object of a discursive-symbolic framework with diverse positions. This framework is built upon gender, ethnicity, class, multiple sexual variables, etc.

When speaking of the evolution of gender studies, one must dedicate some time to studying the contribution made by the anthropologist Gayle Rubin. Rubin retakes Freudian psychoanalysis and the 
structuralism of Lévi-Strauss, in order to unify the concepts of sex and gender in the sex/gender system and make of it the core of any social study. The sex/gender system allows a better understanding of how certain social structures act upon gender and social subjects based on a sexual identity. In this way, it breaks with a natural essence of the sexes that perform within a heterosexual pattern. This thesis by Rubin will become an essential piece in the making of queer theory.

Judith Butler takes up some of Rubin's ideas in some of her early writings in books such as Gender Trouble, Feminism and Subversion of Identity (1990) or Bodies That Matter: On the Discursive Limits of "Sex" (1993). Butler sets out her analysis from the ideological, cultural, and philosophical framework of the dichotomy between biological identity and gender identity. Reading the thoughts of Foucault, Lacan, Wittig, Kristeva, Derrida, and Nietzsche, Butler condemns the "women” category, which belongs to a binary logic and it is the result of structures of domination.

This Butlerian positioning punctuates a change from women studies to gender studies; specifically, the questioning of all identity including generic identity. According to Butler, gender and sex are fabricated. And so, based on this analysis of radical constructivism of sex and gender, Butler sets out to articulate the possibility of shifts and variations in gender. This is all based on the idea that as gender is constructed it is not subject to an unmovable essence.

In Gender Trouble, Butler contrasts the essentialist and naturalistic conception of genders with the thesis that the generic identities are made up in a performative way. The gender identity consists in the same practices in which it is performed without anything else behind. In the same way, body and sex are nothing but the result of a cultural-discursive praxis. Commensurate to the act of speech, gender identities are performative too.

Following this analysis, there is no access to sex which is not culturally afflicted by gender. And thus, sex allocation responds to a cultural (medical and societal) process. This will have a reverberating effect on the binding of identities that abide by a socio-symbolic heterosexual blueprint. Butler points out those acts are modeled on the repetition of norms by generic identities, and this system, in turn, has its own deviation and subversion perils.

Butler does not only engage in literary theory. However, her philosophical judgment has great resonance among literary circles. In Bodies That Matter, for instance, Butler points to a way in which to process texts and cinema scripts, from a gender performative perspective. All these, will have a profound effect on the way gender identity is viewed in the literary theory arena.

Butler's thesis among others, initiates a new way of thinking that tends towards a conceptual troika: race-class-gender, which in turn, leaves sexual difference behind. This troika goes in sync with research by the now called, black literary feminist criticism, on the gay-lesbian as well as the aforementioned queer studies.

The black feminist literary criticism wants to fight the prevailing literary theory with a discourse that may go beyond the critical parameters of a bourgeois and white middle class. In this way the literary critical productions of African and American authors who do not present a homogenous picture is intensified. Nevertheless this research line has in common as relevant, the fact of making visible the diversity of the concept of "woman" and the criticism to the dominant ethnocentrism up till then in the field of feminist literary theory.

In the intervening time, queer theory, emerging from gay and lesbian analysis defies the heterosexual prevalent model and puts forward a new, positive meaning to non-normative identities such as lesbians, gays, transgender, or transsexuals. Borrowing from Foucaultian discourse analysis, queer studies adduce a 
deconstruction of all essentialized identities to understand that identities are a product of power and discursive praxis (López Penedo, 2008, pp. 17-35). Theorists, such as Judith Butler or Eva Kososfsky Sedwick (1990), make way to the queer approach. They propose to carry out an identity policy, opposed to normative identitarian processes as well as highlighting its radical character of discursive-cultural construct.

All up to this point, I have tried to lay forward a journey in which, to begin my closing argument, we can show how the understanding of the sexual difference has developed through contemporary feminist thinking. In the origins of the feminist literary criticism, in the 1960s, and starting essentially from Millett, a criticism of the patriarchal and androcentric discourse on femininity is established. From there we arrive to the vindication of a literature and, in general, of a culture of the female. The female difference consolidates in the French feminist thought that especially with Luce Irigaray theorizes that difference as what remains eccentric to the male dominant reason, to the phallogocentrism. But thinking of a female identity, built around phallogocentric ideology, will allow a theory of deconstruction. This theory, especially in the United States and in the late 1980s, will be paired with understanding that all gender identities (male and female), are nothing but the by-product of a linguistic framework. This is the path taken by the Yale group with Felman or Spivak among many others. And the whole of this process results in the vindication of the deconstruction of all identities. Consequently, the gender is understood as an effect of discourse and power, liable to be proliferated and/or transgressed performatively. In this way we are in the framework of queer theory.

\section{Conclusion}

To sum up the main thesis of all of the above, I could say that the most important issue in my view is the break of the identitarian thinking and how this has marked the philosophical, cultural, and literary scene. And it must lead us to think the place of feminist criticism in this context in which it is still necessary an emancipation project. Or in the words of Seyla Benhabib a political and moral imperative continues to have sense, this is, the imperative of the future interest in emancipation (Benhabib, 1992).

\section{References}

Benhabib, S. (1992). Situating the self: Gender, community, and postmodernism in contemporary ethics. New York: Routledge. Butler, J. (1993). Bodies that matter: On the discursive limits of "sex". London, New York: Routledge.

Butler, J. (1990). Gender trouble: Feminism and the subversion of identity. London, New York: Routledge.

Cixous, H. (1986). Entre l'écriture (Between writing). Paris: Des Femmes.

Cixous, H. (1995). La risa de la medusa. Ensayos sobre la escritura. Barcelona: Anthropos (1ª-1975). ("Le rire de la Méduse”) (The Laugh of the Medusa. Essays about writing). L'Arc, 61, 39-54.

Clément, C., \& Cixous, H. (1975). La jeune née (The young born). Paris : Union générale d’éditions.

Derrida, J. (1967). De la Grammatologie (Of grammatology). Paris: Les Éditions de Minuit.

Derrida, J. (1972). La Disémination (The dissemination). Paris: Seuil.

Felman, S. (1983). The scandal of the speaking body: Don Juan with J. L. Austin, or seduction in two languages. Stanford: Stanford University Press.

Felman, S. (1993). What does a woman want? Reading and sexual difference. Baltimore, Maryland: Johns Hopkins University Press.

Gilbert, S. M., \& Gubar, S. (1998). La loca del desván. La escritora y la imaginación literaria del siglo XIX (The madwoman in the Attic. The woman writer and the nineteenth-century literary imagination). Madrid: Cátedra. (1 ${ }^{\mathrm{a}}-1979$ : The madwoman in the Attic. The woman writer and the nineteenth-century literary imagination. Yale: Yale University Press).

Irigaray, L. (1994). Amo a ti (I Love to you). Barcelona: Icaria. (1 ${ }^{a}-1992$. Je aime a toi. París: Grasset et Frasquelle) (I Love to You: Sketch for a Felicity Within History, Eng. trans. 1993). 
Irigaray, L. (1997a). This sex which is not one. In L. Nicholson (Ed.), The second wave. A reader in feminist theory (pp. 320-330). Nueva York-Londres: Routlegde.

Irigaray, L. (1974b). Speculum de l'autre femme (Speculum of the other woman). Paris: Les Éditions de Minuit. (Speculum of the Other Woman, Eng. trans. 1985 by Gillian C. Gill)

Kristeva, J. (1974). La révolution du langage poétique. L'avant-garde à la fin du XIXe siècle: Lautréamont et Mallarmé (Revolution in poeticlanguage. The vanguard at the end of de XIX century: Lauréamont and Mallarmé). Paris: Editions du Seuil.

Johnson, B. (1998). The feminist difference: Literature, psychoanalysis, race and gender. Cambridge: Harvard University Press.

Johnson, B. (1987). A world of difference. Baltimore: Johns Hopkins University Press.

Johnson, B. (1980). The critical difference: Essays in the contemporary rhetoric of reading. Baltimore: Johns Hopkins University Press.

López Penedo, S. (2008). El laberinto queer. La identidad en tiempos de neoliberalismo (The queer labrinth. Theidentity in times of neoliberalism). Madrid: Editorial Egales.

Millett, K. (1995). Política sexual (Sexual politics). Madrid: Cátedra. (1ª-1970: Sexual Politics. New York: Doubleday).

Moi, Toril (1985). Sexual/textual politics. London: Methuen.

Rodríguez Magda, R. M. (1999). Foucault y la genealogía de los sexos (Foucault and the genealogy of thesexes). Barcelona: Anthropos.

Rubin, G. (1975). The traffic in women: Notes on the "political economy” of sex. In R. Reiter (Ed.), Toward an anthropology of women. New York: Monthly Review Press.

Sedgwick, E. K. (1990). Epistemology of the closet. Berkeley: University of California Press.

Showalter, E. (1986). Toward a feminist poetics. In E. Showalter (Ed.), The new feminist criticism: Essays on women, literature and theory (pp. 125-143). London: Virago.

Showalter, E. (1977). Literature of their own (Showalter, 1977). Princenton: Princenton University Press.

Spivak, G. C. (1993). Outside in the teaching machine. New York \& London: Routledge.

Spivak, G. C. (1985). Three women’s texts and a critique of imperialism. Critical Inquiry, 12(1), 243-261. 